\section{Rise and Functions of New Media in Architecture: An Investigation via Archdaily}

Iş1 Esen¹, ORCID: 0000-0002-0344-5625

Pınar Dinç Kalayc1², ORCID: 0000-0002-1932-9477

\section{Abstract}

With the rapid spread and easy access to the Internet, the concept of digital media has entered all areas of life. Media tools, which are highly related to professions, affected the discipline of architecture as well and changed its dynamics in terms of design, production, marketing, and advertising. In this context, a closer look at the media concept becomes necessary due to its triggering effect on critical thinking in architecture. In this study, 5 functions of digital media (Information, Cultural continuity, Socialization, Creating/Shaping Public Opinion and Entertainment) which were defined by Katz (Katz, 1960), McQuail, D. (1987) and Burton, G., \& Marshall, P. D. (1993) will be introduced in detail and the Archdaily platform, one of the most popular and widely used new media of Architecture, will be analyzed via these functions. For this, 967 posts published by Arcdaily in 2019 were analyzed. In addition to the main hypothesis 'Does Archdaily operate as a new architectural medium?', sub-analyzes was carried out to see how Archdaily contributed to the world of architecture. Findings indicated that Archdaily was active in fulfilling all the 5 functions of media, though 3 functions, which are "socializing", "providing cultural continuity" and "entertaining", were observed to be fulfilled less than giving information and creating/shaping public opinion. Furthermore, qualitative analyses have shown that media functions were associated with the contents of publications. Findings imply the need for digital platforms to increase their activities in all functions equally and even surprise or exceed the 5 functions theory by adding new dimensions.

\section{Keywords}

Digital Media; Architecture; Archdaily

\section{Article Information}

Received:

04.08.2020

Received in Revised Form:

24.12.2020

Accepted:

15.01.2021

Available Online:

30.01 .2021

Article Classification:

Research Article

\section{Contact}

1. Gazi University, Faculty of Architecture, Ankara, Turkey archisilesen@yahoo.com

2. Gazi University, Faculty of Architecture, Ankara, Turkey pinarpinardinc@gmail.com

Esen, I., \& Dinç-Kalayc1, P. (2021). Rise and Functions of New Media in Architecture: An Investigation via Archdaily. GRID Architecture, Planning and Design Journal, 4(1), 1-25. https://doi.org/ I0.37246/grid.776887 


\section{INTRODUCTION}

With the new communication technologies and the Internet that are intensely included in our daily lives, different kinds of relationships and interactions have started to occur between daily life and the environments accessed over the Internet. One of the communication environments provided by the Internet, having an important place in the new communication technologies, is the digital media that shapes the subject of the study. Digital media is responsible for most of the activities that are carried out relationally and interactively. Arklan \& Akdağ's approach underlines that the internet emerges as a communication environment with its rituals, ceremonies, and friendships when it is transferred to digital media (Arklan \& Akdağ, 2016). They state that, although digital media has an important place in daily life due to its offering a separate daily life practice in its environment, it is also influenced by daily life and developments (Arklan \& Akdağ, 2016). Göker states; when people look at the history of communication, it will be realized that all communication tools have emerged and developed to meet a social need such as information sharing and communication (Göker, 2017). Göker underlines that the new media causes a change in the communication practices of the individuals and reorganize the forms of social relations. He states; when evaluated in terms of social effects and consequences, considering the developments in the world, new media environments are effective tools for the emergence and development of social movements (Göker, 2017). For instance; in the 1920s, radio had become a major mass media tool. According to Douglas, people would rather sit at home and listen to the radio rather than go to live music or watch a game. As a result of that; many popular cultural forms had shifted towards radio broadcasting to protect their audience and increase it (Douglas, 2013).

As stated above, the media has an undeniable impact on society. These effects have been classified by media theorists and this classification will be elaborated as ' 5 functions of media' upon in the following. In this context, when the media is so much in people's lives and it concerns everyone closely, the question arises how it relates to the discipline of architecture? In this study, to understand whether online architectural mediums are sufficient in terms of media functions for giving information, cultural continuity, socialization, creating/shaping public opinion, and entertainment for the discipline of architecture. These functions will be considered sufficient if provided equally and above $50 \%$. In the discipline of architecture, online architectural mediums mean; the media, which is informed reader before the theory and books, and where the one can 
follow the architectural agenda quickly. Especially young architecture students follow the agenda from online architectural mediums. In these mediums star architects become stars... Non-star architects use these mediums to become star architects. As it is seen, these online environments have an important place in the large architectural discipline.

In this paper, firstly what the media means will be discussed, then Archdaily platform which is the most visited architectural website worldwide according to the statistics provided by Alexa (Alexa, 2019) will be examined through media theories as a case study. This study is important for academic literature since the digital media's contribution to the architectural discipline has not been studied through media theories before.

\section{Historical \&Theoretical Background}

The dictionary definition of media refers to mass media, mass communication, and medium issues. According to definitions; Mass Media are messages and cultural forms (especially news, information, entertainment, and advertising) that are distributed to large and heterogeneous masses (Chandler \& Munday, 2011). Mass Communication means the messages transmitted to mass media through technological methods and with this feature become a completely modern form of communication. Medium has two meanings; 1 . The tool or unit in which communication takes place is synonymous with the channel. 2. General artistic or technical expression forms or modes (for example photography), the physical means of expression in a representation, ranging from specific materials, tools and methods (Chandler \& Munday, 2011). Besides all these definitions, media is a collection of symbols that contain everything visual and written. The sister concepts of the media are channels, communication, and representation. Digital media, on the other hand, is a new type of representation based on mathematical calculations and algorithms. The transformation of media into new media can be shown in two stages. First, the birth of media tools; image representations, second; is the birth of computational communication tools.

i. From cave paintings to the camera: According to Schmandt-Besserat, as the lives of our ancestors became more complex, about 100,000 years ago, it has led to the development of communication tools, called 'extra somatic memory', which means a memory outside the body, aiming to store data with increasing volumes and recall it when needed (Schmandt-Besserat, 2010). Fischer emphasizes that over time image representations have become standard and abstract and that images were no longer meant a real perceptible thing like a sheep, but rather represented a certain sound value. Fischer states when the Sumerians (3400-3100 BC) began to use these figures systemically, the writing system was formed (Fischer, 2003). Plato (428 -348 BC) thought the writing was an external foreign technology, and today many people think the same about the computer (Urquhart \& Heyer, 2018). Moret states, 'The lightness won and a heavy tool stone left its place to papyrus' (Moret, 2013). After the invention of the papyrus paper in China in the 1st century, it started to be produced in Europe in the 13th century. In the 15th century, Johannes Gutenberg invented the printing press (Urquhart \& Heyer, 2018), which enabled the mass production of books and the rapid spread of information across Europe. Newhall and Beaumont state, through Diorama (the primitive camera), invented by Louis Daguerre in 1839, everyone wanted to 
record the view visible from his/her window, and according to Newhall and Beaumont, media craze had begun (Newhall, 1949).

ii. From analytical machine to microchip technology: In 1833, Charles Babbage started designing the device he would call 'Analytical Machine'. This machine had the most essential features of the modern digital computer (Urquhart \& Heyer, 2018). It used punched cards for data and command entry. After the analytical machine, the telegraph and phone were accepted as the second wave of the new communication revolution (Urquhart \& Heyer, 2018). To move the information, the vehicle had to be moved. Dispatch riders/postmen can be an example of that vehicle, this communication model is called transportation-based communication. According to McLuhan, with the invention of electricity, there was a fundamental transformation where 'transportation' and 'communication' were strictly separated. After the telegraph, radio and phone were developed in the 19th century, according to Urquhart \& Heyer, the phone exceeded many limitations of the telegraph. As the telegraph requires mastering Morse code and advanced literacy, it was not possible to spread it to the houses. Urquhart \& Heyer states that by the end of the 19th century, after the development of microchip technology, which enabled messages to be transmitted further, faster and with less effort, the computer spread to all industries and homes. (Urquhart \& Heyer, 2018).
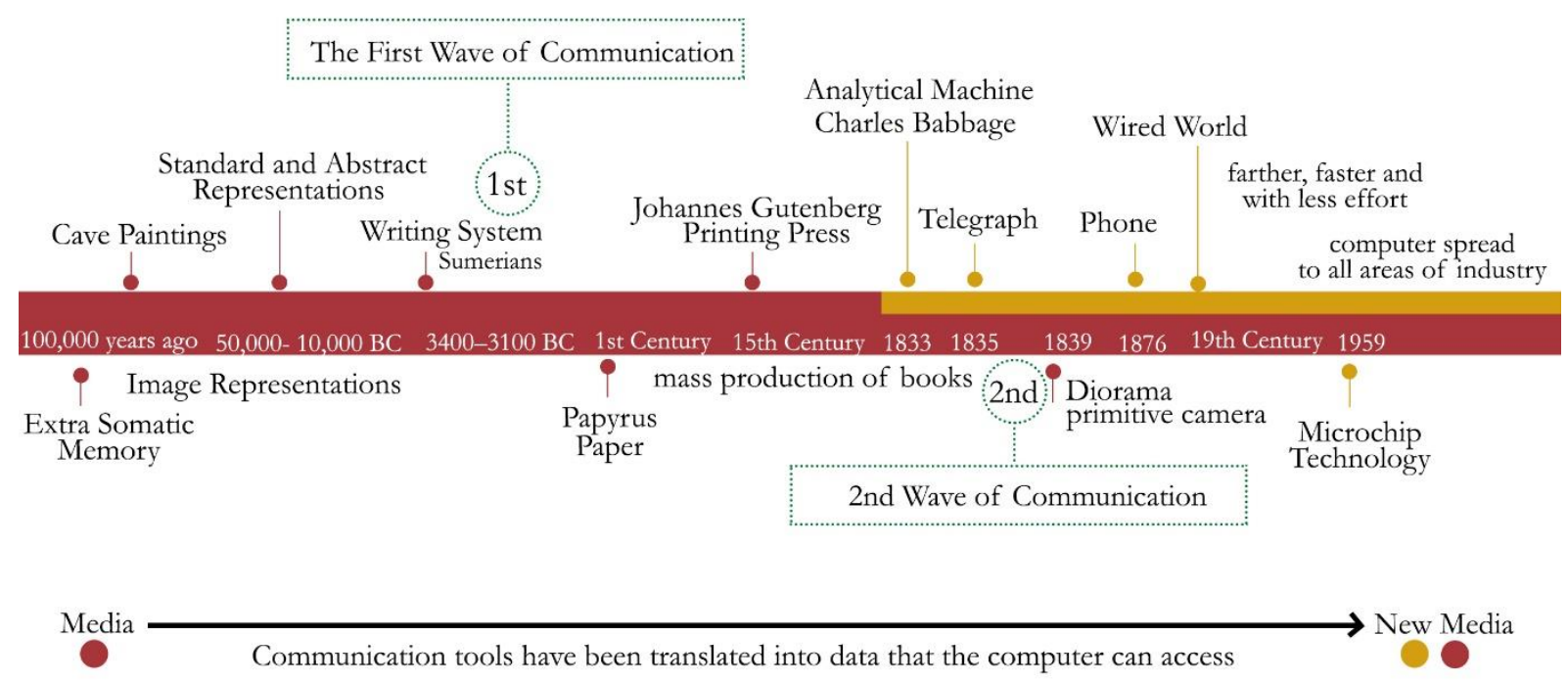

Figure 1. Historical Background of Media

One thing that should be noted in this short history of Media; media tools and computational machines have followed separate paths throughout the history of communication (Figure 1). Urquhart \& Heyer states all existing communication tools have been translated into data that the computer can access (Urquhart \& Heyer, 2018). They underline; the media has become the new media in this way. According to Urquhart \& Heyer; a computer, which is no longer just a calculator, control mechanism, or communication device has turned into a media processor (Urquhart \& Heyer, 2018). Lev Manovich argues that new communication tools now can transform the 
computer's way of presenting and promoting media. According to him; websites, virtual worlds, virtual reality, multimedia, computer games, and computer animations are considered new media formats. Together they will reshape the visual language of contemporary culture (Manovich, 2001). While seeking an answer to the 21 st-century architectural media, Lev Manovich's statement is the basis of the research.

\section{Functions of Media}

In parallel with Auguste Comte's (1798-1857) statement, 'It is necessary to know to foresee and achieve' (Comte, 1830), being informed and knowing has an impact on the changes in societies. According to Katz (Katz, 1960), McQuail, D. (1987) and Burton, G., \& Marshall, P. D. (1993) the media has five basic functions;

i. Information: Giving people information about the events that are happening in society and the world, enabling the creation of visions about ourselves, the environment, country, World, and the entire Universe (Mora, 2008).

ii. Cultural continuity: Transferring social values such as history, tradition, beliefs, and building a bridge between past generations and future generations (Mora, 2008).

iii. Socialization: Providing social unity among the individuals who make up society, making them interact with each other (Mora, 2008).

iv. Creating public opinion: Giving information about the issues that concern society, drawing attention, and creating public opinion in different areas of interest (Mora, 2008).

v. Entertainment: Broadcasting that ensures society having a good time through various programs such as music, contests, series films (Mora, 2008).

According to Oskay (1993) media reconstructs information (Oskay, 1993). According to Klapper media affects societies, media's reconstruction of information affects social and individual infrastructures (Klapper, 1960). Barrett \& Braham state, Media exbibited systematically and periodically by repetition have an intensive shaping and determining effect on individuals, especially children and young people's tendencies, attitudes, emotions, expectations, and behaviors regarding gender, profession and politics' (Boyd-Barrett \& Braham, 2013). According to Boyd-Barrett \& Braham, the media has the power to influence individuals' knowledge, opinion, attitude, emotions, and behavior (Boyd-Barrett \& Braham, 2013). They assert; not only individuals but also social groups, organizations, social institutions, in short, the entire society and culture are within the boundaries of the media's influence. Klapper collects the media's impact on changing society in 3 major categories; 1 . Modification and Conversion, 2. Making minor changes and 3. Strengthening (Klapper, 1960).

All these indicate that media is a concept that has existed since the early ages of humanity and shaped society and social behavior. The media, which has undergone much evolution until today, has 5 functions. On the other hand, media functions have never been measured or exemplified directly in the media of architecture framework. In the next section, the new media will be observed within the framework of the media of architecture. 


\section{The New Media of Architecture}

Purdy (2008) states that before photography and electronic networks, architectural images were transported across the Alps by tourists and pilgrims. These architectural images were architectural drawings, treatises, and personal memories. He states that architectural publications started to appear in this way; Purdy claims that Andrea Palladio (1508-80) / Four Books on Architecture (1570) book emerged from this pre-modern media cycle activity (Purdy, 2008). Karaca states the most effective tool in the promotion of architecture is the media (K Karaca, 2010). She underlines that all the major communication and broadcast organs, the newspapers, magazines, books, brochures, television, cinema, radio, internet and billboards in the streets, written, printed, verbal and visual, show how and where mass media are included in our lives. According to her thought, the power of the media is proportional to its uncontrolled growth and its place in the social environment (K Karaca, 2010). Başaranoğlu states, the architects, who were shown as the genius of their era, announced their names in direct proportion with the governing powers of that period. The architects, who are mostly close to the rulers, are shown as the media names of the period (Başaranoğlu, 2018). Today, architectural media has turned into online architectural platforms. Such as; Archdaily, Dezeen, Designboom, Architectural Review, Worldarchitecture, Architecturalrecord, Architect magazine, Archinect, Architectural Digest, and so on... According to Rubio and Rubén, the history of architecture has changed (Cimadomo, García Rubio, \& Shahdadpuri Aswani, 2018). They thought, From our point of view, there is not only one story present today, but several, even related, stories to present.' (Cimadomo et al., 2018). Also, they underline online platforms such as Archdaily, Dezeen, Worldarchitecture or Divisare deliver a vast number of built and unbuilt projects every day, generating a tremendous flow of data difficult to manage and classify. On the other hand, Ballantine states, an enormous amount of architecture designed worldwide, could offer great insights on the understanding of architectural histories (Arnold, Ergut, \& Ozkaya, 2006).

\section{THE STUDY}

\section{Methodology}

The study proposes a multidimensional assessment model for diagnosing how far the newly emerged media of architecture is serving digital media requirements, therefore diagnosing the contribution of digital media to contemporary architectural culture. The approach classifies requirements/criteria into five groups: (i) Information, (ii) Cultural continuity, (iii) Socialization, (iv) Creating public opinion, and (v) Entertainment, which are the five functions of digital media defined by Katz (1960), McQuail, D. (1987) and Burton, G., \& Marshall, P. D. (1993). Archdaily's website was chosen as the case study since it is the most visited architectural website according to the statistics provided by Alexa (Alexa, 2019).

This study comprises two types of research; quantitative and qualitative.

i. The purpose of Quantitative research is to determine 'How much' the newly emerged media of architecture is serving to digital media requirements, therefore diagnosing the contribution of digital media to contemporary architectural culture? 
ii. The purpose of Qualitative research is to determine 'How' the newly emerged media of architecture is serving digital media requirements, therefore diagnosing the contribution of digital media to contemporary architectural culture?

First, the criteria table was established to settle the meaning and diagnosis criteria for every 5 functions of the new media (Table 1). Second, Archdaily's history/story and outline were investigated. In line with the scope given in this criterion table, seven headlines of Archdaily; the 'Architectural News', 'Article', 'Competitions', 'Events', 'Sponsored Article', 'Architecture Books' and 'Interview' were examined through 967 posts, representing one year (2019) performance of the site. Due to the difficulty in accessing content older than 2019, the inability to communicate with Archdaily editors, and lack of time for a large number of data, 2019, the last completed year, were determined as the limitation of the research. If sufficient time-data access is provided, this study can be carried out more comprehensively. Table 2 provided the quantitative data for diagnosing how much Archdaily has been serving the contemporary architectural culture. Figure 5 shows the findings of qualitative research. It took 3 weeks to collect the publications and analyze the data. The research was conducted in June 2020. Figure 2 displays the research process and structure in detail.

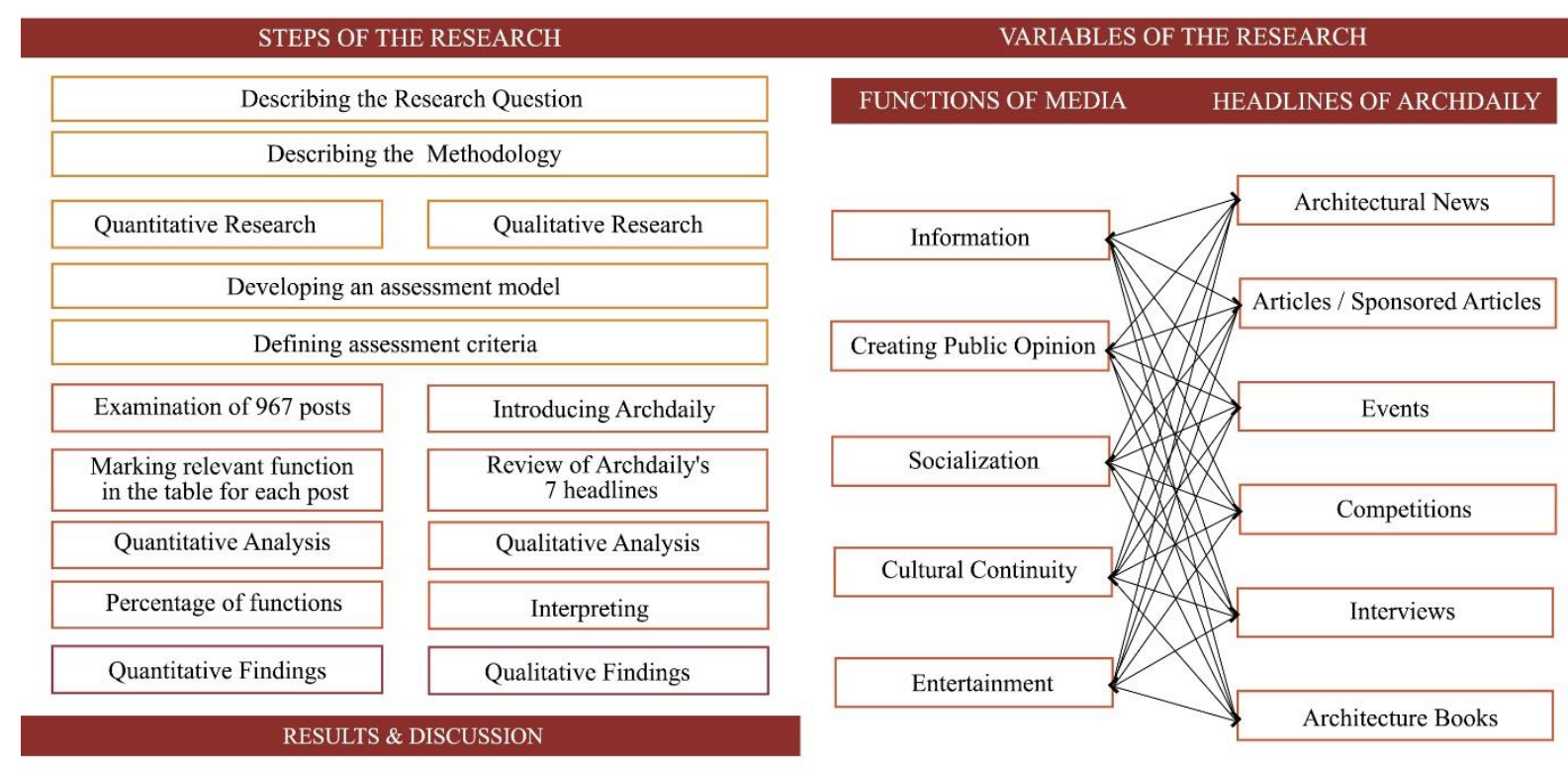

Figure 2. Research structure, the process, and content

\section{Research Questions}

The quantitative research question was related to functions: On what percentages the information, creating public opinion, socialization, entertaining and cultural continuity variables were affecting the architectural environment? The purpose of qualitative research is to understand how the relationship of the variables is formed and reveal the patterns. The qualitative research question was: How the media functions are manifested in Archdaily? Briefly, this question tries to solve one major research problem: How does Archdaily operate as a new architectural medium? 
In this article new architectural media has been accepted just like the new media. Any kind of virtual context; article, image, design, or verbal context published on the internet environment. Briefly non-printed media have been accepted as the new architectural media. And the environments in which these non-printed media circulate have been accepted as New Architectural Medium.

\section{Archdaily Platform}

\section{i. The Birth of Archdaily}

As indicated in Alexa (Alexa, 2019), Archdaily is the world's most visited architecture website. To study the new media of architecture, the Archdaily platform was chosen as the case. Archdaily was born in late 2008 as Plataformaarquitectura.cl, a Spanish site (Archdaily, 2019a). Rubio and Rubén states, Archdaily adopted English as a second language to reach a bigger audience and established the Archdaily.com domain which duplicated the pair's contents to target more local visitors (Cimadomo et al., 2018). According to Rubio and Rubén, Archdaily was developed as a resource to provide architecture documentation and is currently being accessed every month by almost 13 million users (Cimadomo et al., 2018).

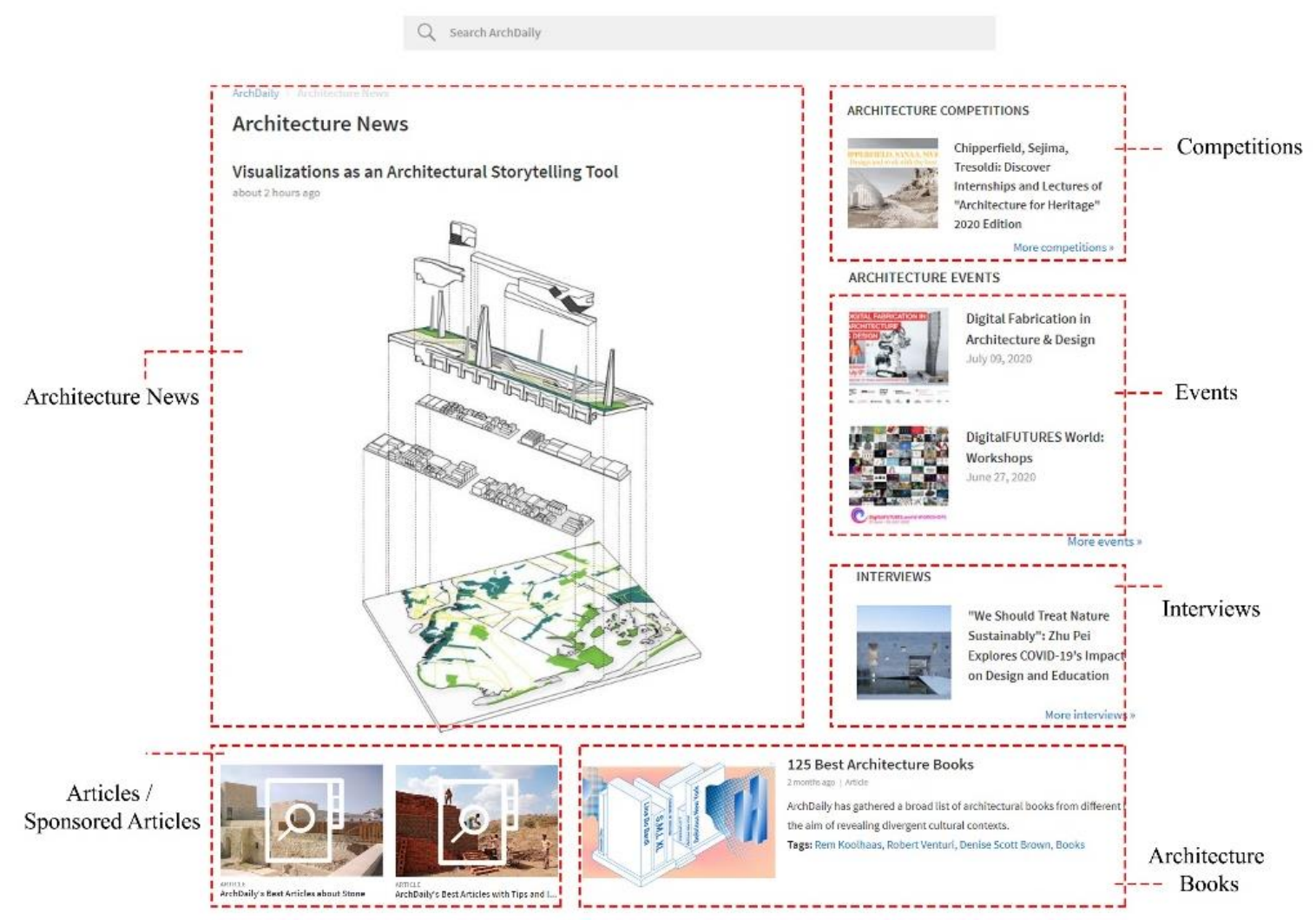

Figure 3. Headlines of Archdaily

Archdaily's mission is stated as follows:

In 2008, while working as architects, our founders realized that there was no place for their peers to experience the latest projects, products, and trends. So, we decided to build it. We 
began as a platform to collect and spread the most important information for architects seeking to build a better world. Today, we are an ever-evolving tool for anybody who has a passion and determination to shape the world around them, including the 13.6 million readers that visit ArchDaily every month (Archdaily, 2019a).

\section{ii. Statistics}

According to the statistics provided by Alexa (Alexa, 2019), Archdaily scores 2,944 as a global popular site measured from an algorithm which takes into account individual users and number of pages visited and has an audience leading from China (14.3\%) and the United States (12.3\%) (Alexa, 2019). According to Rubio and Rubén, those statistics showed this firm's dominant role in the architectural area (Cimadomo et al., 2018). Rubio and Rubén state, such websites were the first medium to inform about architectural events, new projects, and innovation in materials (Cimadomo et al., 2018).

Unlimitedness of archives is one of the most important features of digital media. Boyacıoglu, Erkarslan and Erenoğlu state that the printed architecture magazines that publish twelve issues per year could promote 600 buildings on average (Boyacığlu D.B. \& T., 2015). As reported on the official page of Archdaily, although Archdaily was established in 2008, it has published close to 30,000 shipments and close to 15,000 structures in 6 years (Archdaily, 2019a). It is possible to say that traditional journals could not reach the number of buildings that Archdaily shared and promoted within the same period. This statement emerges from the importance of the capacity of digital media by the number of circulating building. It is possible to claim that Archdaily occupies a large scale in the architectural community.

\section{iii. Partnerships}

According to Veil and Ojeda, partnerships were equal communication relationships with groups or organizations that had an impact on an organization. They state that the partnership aims to facilitate the communication process from the institution to stakeholders and the media (Veil \& Ojeda, 2010). In line with Veil and Ojeda's statement, to make the digital media more open and accessible for the architectural environment, Archdaily also collaborates. Architectural Review (AR), Hunter Douglas, LafargeHolcim, Harvard University, Sherwin-Williams, Saint-Gobain, American Standard Companies, Autodesk, Metal Fabrics, Equitone, and Architonic are the partnerships with the Archdaily platform (Archdaily, 2019b).

\section{Variable 1: The Archdaily Headlines Dataset}

\section{i. Architecture News}

Looking at the 2019 news of the Archdaily platform, the year was started with a general evaluation of 2018 (The Best Architecture of 2018); in the middle of the year, trends of 2019 was published (The Trends that Will Influence Architecture in 2019), when it comes to December, (The 20 Most Bookmarked Projects in 2019) was published as a review of 2019. The most read news in Archdaily (2019) were as follows: "Under (Underwater Restaurant) / Snohetta", "Tiny Holiday Home / i29 interior architects + Chris Collaris", "The Skyscape Rooftop House / WARchitect" , "Four Leaves 
Villa / KIAS", "Petry Retreat / N+P Architecture", "Planter Box House / Formzero", "Musée Yves Saint Laurent Marrakech / Studio KO" m8, "911-VILLA / VACO Design", "House BRAS / DDM Architectuur", "Soul Garden House / Spacefiction Studio", "Omah Boto House / Andyrahman Architect", "Garden Hotpot Restaurant / MUDA-Architects", "Hood River Residence / Scott | Edwards Architecture", "ANHS House / G+ Architects", "Hamra / Collectif Encore", "Woodhouse Hotel / ZJJZ", "Enrico Fermi School / BDR bureau", "All House / Gui Mattos", "Flick House / DELUTION" (Archdaily, 2019).

\section{ii. Article / Sponsored Article}

When the article headline was examined, it would not be wrong to say that articles are a kind of documentation of architectural history in the 21 st century. Archdaily has monthly topics under the title of the article. These topics are; Representation in Architecture - February 2019, Home - March 2019, Public - April 2019, Use \& Reuse - May 2019, Travel - June 2019, Resiliency - July 2019, Accessibility - August 2019, Work - September 2019, Innovation - October 2019, Under The Radar November 2019, 2019 In Review - December 2019 (Archdaily, 2019).

Most read articles of 2019 were; 'Storage Solution for Small Houses: Useful Examples', 'Bringing the Outdoors Inside: The Benefits of Biophilia in Architecture and Interior Spaces', 'What is the Future of Concrete in Architecture?', '16 Brick Cladding Constructive Details', '6 Steps for Designing Healthy Cities', '20 TED Talks on how Architecture can Change the World', 'The Creative Process of the Four Pioneers of Modern Architecture', 'A Series of Maps Reveals the Difference in How Cities are Perceived by Tourists and Locals', 'Modern Morocco: Building a New Vernacular', 'What Would 6 Cities of the United States be like if Frank Lloyd Wright or Robert Moses had Designed Them?' (Archdaily, 2019).

iii. Event

In 2019, the most influential events were: Arata Isozaki, Pritzker Prize 2019, Building of the Year 2019: Richness of Firms, Regions, and Materials, ArchDaily in Spanish's ODA 2019: Architecture from South America, ArchDaily Brazil's ODA 2019: A Public Building, A Museum, and A House, ArchDaily China's Building of the Year, ArchDaily's 2019 Refurbishment in Architecture Awards: Voices from the States, Italy, and China, ArchDaily \& Strelka Award's First-Ever Edition, Chicago Architecture Biennial 2019, Bi-City Shenzhen Biennale of Urbanism\Architecture 2019, Lisbon Architecture Triennale 2019, Sao Paulo Architecture Biennial 2019, Chile Architecture Biennial 2019, XI BIAU: The Most Relevant Architecture Across Ibero-America, Venice Biennale 2020 Reveals Theme (Archdaily, 2019).

\section{iv. Competition}

Among the competition projects published in Archdaily in 2019, the projects that are most read and attracted the attention of the architectural community are as follows:

In the built competitions category; 'WERK Snohetta's New Maritime Center in Denmark', 'OMA's Adaptable Masterplan for Milan's Disused Railways', 'Dorte Mandrup's Cultural Building in Norway', 'Fundamental Approach Architects' Unconventional Mosque', 'Estudio Aisenson ASN 
/ nOISE's Bridge and Boulevard for Buenos Aires Expo 2023', 'LAVA Aspect's Central Park for Ho Chi Minh City', 'Zaha Hadid Architects and Esplan's Rail Terminal in Estonia', 'OMA + Being's Renovated VDMA in Eindhoven’ (Archdaily, 2019).

In the ideas competitions category; 'eVolo Skyscraper Competition 2019', NASA's 3D Printed Habitats on Mars', 'RE School Competition for the Future of Remote Education', 'A School Made from Recycled Plastic in Mexico', 'ARKxSite Mausoleum Competition in Portugal', 'SKYHIVE Skyscraper Challenge 2019', 'UED's City of the Future Competition', 'Teamakers Guest House Competition', 'Urban Zoo Coworking Competition' (Archdaily, 2019).

v. Architecture Book

Under the title of architecture books, Archdaily promotes the latest published books to its readers. Although the book promotion is not very frequent in Archdaily, some books in 2019 were as follows;

'Manual of Section by Paul Lewis, Marc Tsurumaki, and David J. Lewis published by Princeton Architectural Press (2016)', 'Ryue Nishizawa / SANAA (Source Books in Architecture)', 'Moscow's Underappreciated Architecture Digitalized Book', 'From Concrete to Paper: Tadao Ando's Recent Works Displayed in New Monograph', 'Zupagrafika / Eastern Blocks', 'Sarah Manning and Peter Feldmann / Spaceagency Guide to Wayfinding', 'Urban Design Lab Handbook', 'Collin Anderson / What is Affordable Housing?' (Archdaily, 2019).

\section{vi. Interview}

When the interview category is examined in Archdaily case, it offers the opportunity to the architectural community to listen to the architect's project from her/him or to get information from speakers from different disciplines who are interested in architecture.

The most read interviews from Archdaily in 2019 were; An Interview with TED Founder and Architect, Richard Saul Wurman, "Diversity Fosters Creativity": Rohan Silva on Building a Creative Community for Los Angeles, Heatherwick and MAD on Innovation in Architecture, Carlo Ratti and Winy Maas Discuss Facial Recognition and the Shenzhen Biennale, Erieta Attali: "I Create Images That Capture an Identity of Place", "One Day All the Dreamers Will Get Together to Build a Fantastic World": In Conversation with Massimiliano and Doriana Fuksas, Steven Holl: "I am interested in Architecture that Speaks to the Soul", Junya Ishigami: "Innovation Comes From Each One of Us", Airbnb Environments Principal Designer Rachael Harvey Talks Interior Design and the Future of Workplace, David Basulto and Varvara Melnikova on Internet and Education, There's No Good Architecture Without Daylight: How to Promote Designs Molded and Nurtured by Light, rat [LAB] Studio Founder Sushant Verma: 'Most of Us Are Not Even Ready for the Present', Hello Wood Team on How to Create a Strong Community in a Week, Open More Doors: Groupwork + Amin Taha, Open More Doors: TOPOTEK 1, Open More Doors: Supervoid, Open More Doors: Studio Gang, Open More Doors: O-Office (Archdaily, 2019). 


\section{Variable 2: Assessment Criteria}

Definition of each function will be recalled and examples that relate the function with the Archdaily platform will be introduced (Table 1).

Table 1. Function-example connections from Archdaily platform

\begin{tabular}{|c|c|c|}
\hline FUNCTION & SAMPLE & VISUAL \\
\hline \multirow{2}{*}{ Information } & $\begin{array}{l}\text { 'How to Implement Passive Solar Design in Your } \\
\text { Architecture Projects' } \\
\text { In this article, passive solar systems were introduced and } \\
\text { the reader was informed by examples. }\end{array}$ & \\
\hline & $\begin{array}{l}\text { 'The Trends that Will Influence Architecture in 2019' } \\
\text { In this article, the reader was informed by a list of the most } \\
\text { popular architectural ideas which could be continued } \\
\text { throughout } 2019 .\end{array}$ & \\
\hline \multirow[t]{2}{*}{ Cultural Continuity } & $\begin{array}{l}\text { 'Continuity and Sensitivity Drive the Designs of Ricardo } \\
\qquad \text { Bak Gordon' } \\
\text { In this article, the past, present, and future design examples } \\
\text { were given to explain the design strategy and approaches of } \\
\text { successful companies. }\end{array}$ & \\
\hline & $\begin{array}{l}\text { 'Arata Isozaki, Pritzker Prize 2019' } \\
\text { The Pritzker Prize has cultural continuity as it is an } \\
\text { architecture award given every year since } 1979 .\end{array}$ & \\
\hline \multirow{2}{*}{ Socialization } & $\begin{array}{l}\text { '2019 Young Architect Conference' } \\
\text { Conferences can be cited in this category as they are social } \\
\text { environments where people come together and } \\
\text { communicate with each other. }\end{array}$ & \\
\hline & $\begin{array}{l}\text { 'Bauhaus Summer School 2019' } \\
\text { This program, in which more than } 300 \text { students can } \\
\text { participate, is an example of socializing. }\end{array}$ & \\
\hline \multirow{2}{*}{ Creating Public Opinion } & $\begin{array}{l}\text { '121 Definitions of Architecture' } \\
\text { There were } 121 \text { different definitions of architecture in this } \\
\text { article. It was aimed that the reader creates her/his } \\
\text { definition. }\end{array}$ & $\begin{array}{l}121 \text { DEFIN } \\
\text { OF ARCHIT } \\
\text { A }\end{array}$ \\
\hline & $\begin{array}{l}\text { 'What Would } 6 \text { Cities of the United States be like if Frank } \\
\text { Lloyd Wright or Robert Moses had Designed Them?' } \\
\text { There are several reader comments under this article. } \\
\text { Hence the article was successful in creating public opinion. }\end{array}$ & $2 x^{3} x^{2}+x^{2}$ \\
\hline
\end{tabular}




\begin{tabular}{|c|c|c|}
\hline FUNCTION & SAMPLE & VISUAL \\
\hline \multirow[b]{2}{*}{ Entertaining } & $\begin{array}{l}\text { 'Alfredo Thiermann and Artifacts: Understanding } \\
\text { Architectural Space Through Sound' } \\
\text { Since a broadcast was made via Youtube, this content was } \\
\text { evaluated in the entertainment category. }\end{array}$ & \\
\hline & $\begin{array}{l}\text { 'David Basulto and Varvara Melnikova on Internet and } \\
\text { Education' } \\
\text { As Mora states; Broadcasting enables society to have a } \\
\text { good time through various programs such as music, } \\
\text { competitions, TV series, etc. (Mora, 2008). Therefore this } \\
\text { content is suitable for the entertainment category. }\end{array}$ & ÀRCHDAILY \\
\hline
\end{tabular}

\section{FINDINGS}

Variable 1: The Archdaily Headlines Dataset was given above. Variable 2: Assessment Criteria of the study were determined and examples were given above. This section highlights the relationship between the two variables to be examined to answer the question: How does Archdaily operate as a new architectural medium?

First, Quantitative research will be performed according to one year (2019) performance of Archdaily for diagnosing how much Archdaily has been serving the contemporary architectural culture. Second, quantitative research will be analyzed to define 'How' the newly emerged media of architecture is serving to digital media requirements, therefore diagnosing the contribution of digital media to contemporary architectural culture.

\section{Functional Performance of Archdaily}

\section{Quantitative Research}

To diagnose what percentages the information, cultural continuity, socialization, public opinion, and entertaining variables were affecting the architectural environment via Archdaily, 967 posts were examined and reviewed. Each post was read one by one and marked in the relevant column in table 2, according to functions of media. One year (2019) operations of Archdaily was studied in terms of function-example connections and how much Archdaily is serving to digital media requirements diagnosed (Figure 4). 
Table 2. A Year (2019) operations of Archdaily

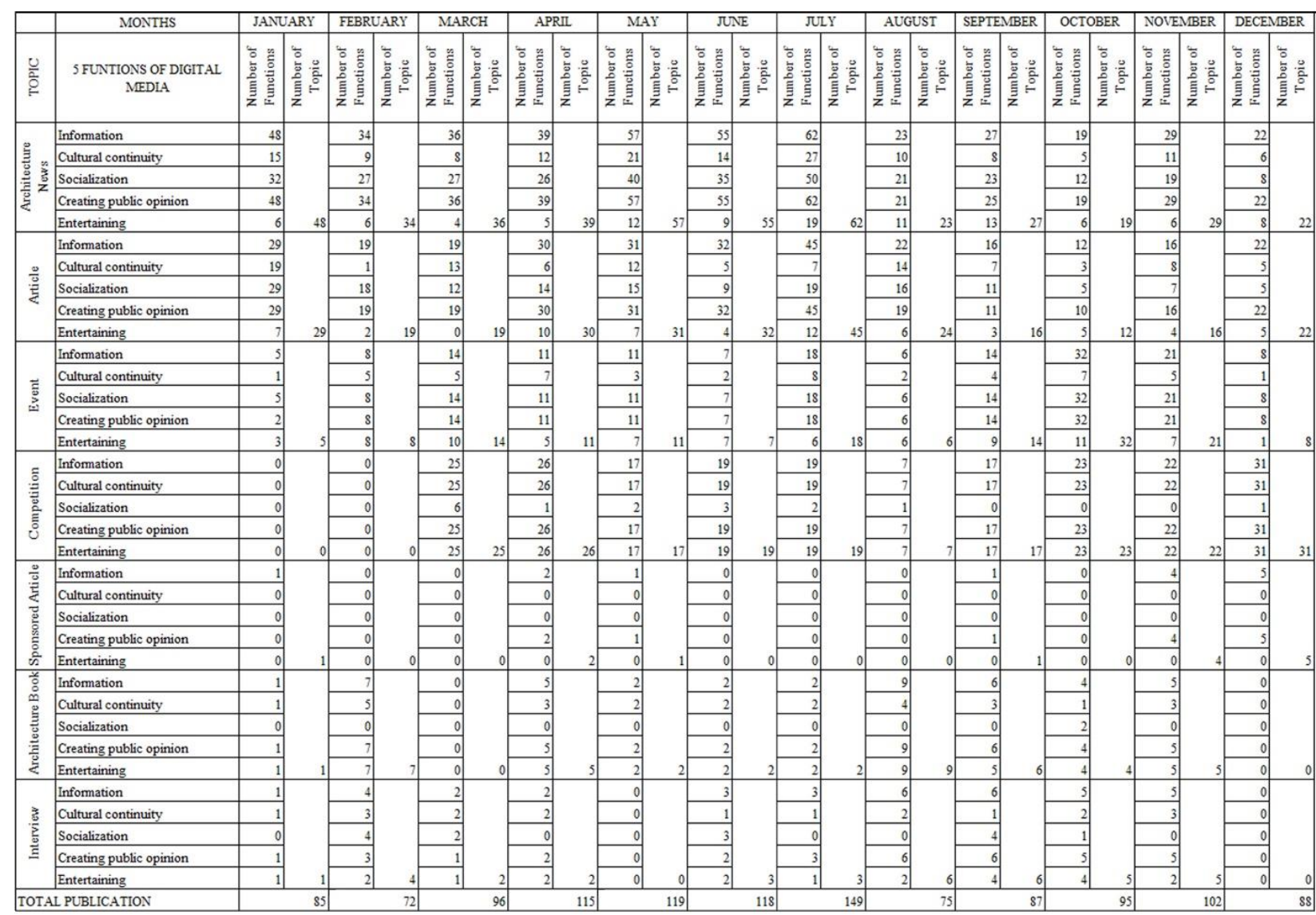

Table 2 diagnosed the functional performance of Archdaily. Figure 4 summarizes the effects of the variables (5 functions) that affect the architectural environment. Archdaily platform provides 5 functions of digital media as; 84,07\% 'Information', 82,94\% 'Creating Public Opinion', 41,78\% 'Socialization', 39,40\% 'Cultural Continuity' and 38,16\% 'Entertainment', respectively (Figure 4). It should be kept in mind that there are still unexamined functions to provide the new media environment. Therefore, people should look at the results as 'not yet reliable' yet, still, the authors take responsibility for the results within the frame and limitations of the present research.

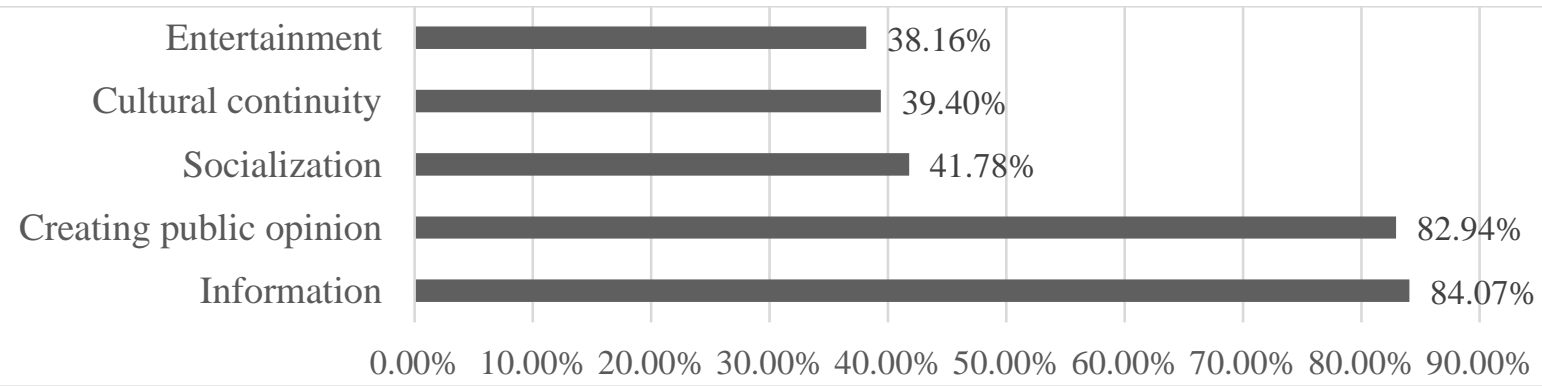

Figure 4. Distribution of posts that have published on Archdaily in 2019 according to the 5 functions of the media. 


\section{Archdaily Headlines and Its Correlations with Functions}

\section{Qualitative Research}

The data (Variable 1: The Archdaily Headlines Dataset) has been collected above. Qualitative research will be evaluated within the scope of this dataset. In this section, the relationship of variables will be carried out under the scope of 30 subtitles (Variable $1 \times$ Variable 2). These titles are necessary to observe the relationships of each variable. Each title has been evaluated within the definition of media functions. The original finding of quantitative research will be given in figure 5 .

\section{Architecture News $x$ Information}

When the Dataset was examined, it was seen that all news in the Architecture News category gave information about the project to the architectural environment. That information is generally about; the architect, square meter, place of construction, and the material used in the project. Therefore, the Architecture News $\times$ Information relationship appeared to be strong.

\section{Architecture News $x$ Cultural Continuity}

Only two of the projects (911-VILLA / VACO Design, Woodhouse Hotel / ZJJZ) in the dataset mentioned traditional methods and established a cultural connection with the past. For this reason, it is possible to claim that the Architecture News $\times$ Cultural Continuity relationship is not as strong as the Architecture News x Information relationship.

\section{Architecture News $x$ Socialization}

Architecture News $\times$ Socialization relationship was not found sufficient because the projects in the news headline are related to public architecture, Architectural News contents provided information about various projects. There are no activities that provide an online or physical socialization environment like the examples mentioned before in the Assessment Criteria table.

\section{Architecture News $x$ Creating Public Opinion}

To Architecture News x Creating Public Opinion relationship to be strong, the publications should both inform and interest the society. It had been observed above that all architecture news informs the architecture society. The criterion that 'drawing attention' and 'creating interest' had been measured by whether there was a comment under the news or not. Since there was not any comment under the examined Dataset, no link could be established in the Architecture News $x$ Creating Public Opinion correlation.

\section{Architecture News x Entertainment}

Within the given data in Variable 1, the content that fulfills the definition of entertainment function had not been found. For this reason, no link could be established in the Architecture News $x$ Entertainment correlation. 


\section{Article / Sponsored Article x Information}

When the articles had been evaluated, it has seen that each article was intended to inform the architectural community. Article 'What is the Future of Concrete in Architecture?' is a good example of this statement. It had been observed that this article aims to inform the architectural community about the frequency and usage methods of concrete. As observed in this article, the purpose of informing the architectural environment was observed in other articles. Hence Article / Sponsored Article x Information relationship had appeared strong.

\section{Article / Sponsored Article x Cultural Continuity}

It has been observed that; '16 Brick Cladding Constructive Details', '20 TED Talks on how Architecture can Change the World', 'The Creative Process of the Four Pioneers of Modern Architecture', 'Modern Morocco: Building a New Vernacular' articles have mentioned tradition, beliefs and connecting them with past generations. Because of these, Article / Sponsored Article $x$ Cultural Continuity connection has existed but not all articles have this correlation.

\section{Article / Sponsored Article $x$ Socialization}

The socialization function has been observed only in "20 TED Talks on how Architecture can Change the World" content. Since 'TED Talks' is an activity that appeals to a large audience where people come together, communicate, and interact. Therefore, although the Article / Sponsored Article $x$ Socialization relationship is weak yet still the correlation has existed.

\section{Article / Sponsored Article x Creating Public Opinion}

It has been observed that; 'Storage Solution for Small Houses: Useful Examples', 'Bringing the Outdoors Inside: The Benefits of Biophilia in Architecture and Interior Spaces', 'What is the Future of Concrete in Architecture?', '16 Brick Cladding Constructive Details', '6 Steps for Designing Healthy Cities', '20 TED Talks on how Architecture can Change the World', 'The Creative Process of the Four Pioneers of Modern Architecture', 'Modern Morocco: Building a New Vernacular' and 'What Would 6 Cities of the United States be like if Frank Lloyd Wright or Robert Moses had Designed Them?' articles have commented under their articles. Therefore, it is possible to claim that there has been Public Opinion. According to these comments, those articles had been attracted to the attention of society. Article / Sponsored Article x Creating Public Opinion analyses advances the idea that the correlation has been strong.

\section{Article / Sponsored Article x Entertainment}

According to the definition of entertainment function, only two articles ('20 TED Talks on how Architecture can Change the World' and 'What is the Future of Concrete in Architecture?') fulfill the Article / Sponsored Article $\times$ Entertainment correlation. The reason that these two articles provide the entertainment function is the video-sharing that Archdaily broadcast via YouTube. Article / Sponsored Article $\times$ Entertainment correlation has existed, but not as strong as the other 4 functions. 


\section{Event x Information}

When the event category had been observed, it appeared that events aim to make announcements rather than to inform the architectural environment. For instance, in 'Arata Isozaki, Pritzker Prize 2019' article is an announcement for the architectural community that Arata Isozaki got the Pritzker Award. The same comment can be made for each article. Hence Event $x$ Information correlation had not been found.

\section{Event x Cultural Continuity}

Cultural continuity function has been observed in the event category since some biennials and awards are traditionally organized every year. These traditional events are; Pritzker Prize, Building of the year, Sao Paulo Architecture Biennial, Chile Architecture Biennial, Chicago Architecture Biennial, and Bi-City Shenzhen Biennale of Urbanism $\backslash$ Architecture. For this reason, all the articles that given in the dataset provide Event $x$ Cultural Continuity correlation.

\section{Event x Socialization}

Since the event category hosts various exhibitions, biennales, openings, and workshops, it aims to create a socializing platform within the architectural culture. All events that given in (variable 1) has been found fulfilling the socialization function. It is possible to claim that the Event $x$ Socialization correlation is the strongest in the event category.

\section{Event x Creating Public Opinion}

Only two articles (Arata Isozaki, Pritzker Prize 2019, and Venice Biennale 2020 Reveals Theme) in the event category provide public opinion definition. It has been observed that those articles contained comments from the readers. It can be said that Event $x$ Creating Public Opinion correlation should strengthen itself.

\section{Event x Entertainment}

Only the 'Venice Biennale 2020 Reveals Theme' article fulfill the requirements of entertainment function. Because 'Venice Biennale 2020 Reveals Theme' article has a video broadcast via YouTube. This video is an interview from Hashim Sarkis 'How Will We Live Together?: Hashim Sarkis on the Venice Biennale 2020'. Therefore Event x Entertainment correlation has existed, but not as strong as the other Event correlations.

\section{Competition x Information}

It has been observed that the headline of architectural competitions firstly aims to announce the winners of the competition. Second, architectural competitions aim to provide information about the design principles of the awarded project. All these indicated that the contents of the competition primarily aimed announcement and providing information to the architectural community has been observed to be a side function. Therefore Competition $\times$ Information correlation has existed, but it is not strong. 


\section{Competition x Cultural Continuity}

It has been observed that there were some competitions like 'eVolo' that were opened traditionally every year. So competition title has a 'Cultural Continuity' function. Although there is cultural continuity in the competition headlines, it was found to be a weak correlation since only one article 'eVolo Skyscraper Competition 2019' fulfilled this correlation.

\section{Competition x Socialization}

When the competitions were examined, it was seen that the colloquium was organized at the end of all competitions. Colloquiums and award ceremonies are usually held in a physical environment and bring many people from the profession together. Since it will not be wrong to say that competitions provide an opportunity to physical environments where people can socialize and they strengthen the Competition $\times$ Socialization correlation.

\section{Competition x Creating Public Opinion}

All competition articles have been observed in (Variable 1) and it has appeared that 'OMA's Adaptable Masterplan for Milan's Disused Railways', 'Fundamental Approach Architects' Unconventional Mosque', 'Estudio Aisenson ASN / nOISE's Bridge and Boulevard for Buenos Aires Expo 2023', 'LAVA Aspect's Central Park for Ho Chi Minh City', 'OMA + Being's Renovated VDMA in Eindhoven' articles have comments from the readers. It could be not wrong to say that those competitions attracted the architectural society, and society has an opinion to write a comment under the publication. Therefore Competition $x$ Creating Public Opinion relationship was found strong.

\section{Competition x Entertainment}

All competition articles have been reviewed in the variable 1 dataset and no competition has been found to define the entertainment function. Therefore, there was no link between the competition and the entertainment category.

\section{Architecture Book $x$ Information}

Books were reviewed in architectural books headline. It is seen that this category mostly provides information function since all books are intended to documentations of information. Therefore, the relationship between Architecture book x Information was strong.

\section{Architecture Book x Cultural Continuity}

It has been observed that 'From Concrete to Paper: Tadao Ando's Recent Works Displayed in New Monograph' book has a traditional value. Ando's book draws a picture of contemporary architectural culture, therefore contributes to the function of cultural continuity. The relationship between Architecture Book x Cultural Continuity existed. 


\section{Architecture Book x Socialization}

The socialization environment is provided only in book promotion activities. Socialization function was only fulfilled in the 'Book Launch: Urban Design Lab Handbook' article. Hence it is possible to say that the Architecture Book $\times$ Socialization relationship needs improvement.

\section{Architecture Book x Creating Public Opinion}

It has been observed that; 'Manual of Section by Paul Lewis, Marc Tsurumaki, and David J. Lewis published by Princeton Architectural Press (2016)', 'Moscow's Underappreciated Architecture Digitalized Book' and 'From Concrete to Paper: Tadao Ando's Recent Works Displayed in New Monograph' books have comments from the Archdaily readers. This shows people have an opinion about the books. Therefore, Architecture Book $\times$ Creating Public Opinion relationship existed, but not for all books.

\section{Architecture Book $x$ Entertainment}

The entertainment function had been found in only one post (Book Launch: Urban Design Lab Handbook). This function has been fulfilled by publishing a video that is related to the book via Archdaily. Therefore, Architecture Book x Entertainment relationship should be developed.

\section{Interview $\boldsymbol{x}$ Information}

It can be said that the interview headline is just like the Architecture news headline. It has been observed that both headlines aim to inform the architectural society. It was observed that each interview informs the society about the interviewee, so it has emerged that the Interview $x$ Information relationship is strong.

\section{Interview x Cultural Continuity}

It has been observed that; 'An Interview with TED Founder and Architect, Richard Saul Wurman', 'Heatherwick and MAD on Innovation in Architecture', 'Carlo Ratti and Winy Maas Discuss Facial Recognition and the Shenzhen Biennale, 'Open More Doors: O-Office', 'Airbnb Environments Principal Designer Rachael Harvey Talks Interior Design and the Future of Workplace' and 'David Basulto and Varvara Melnikova on Internet and Education' interviews are related with tradition and connecting with past generations. Therefore, Interview $x$ Cultural Continuity relation existed, but not for all interviews.

\section{Interview $\mathbf{x}$ Socialization}

Interviews take place between 2 people. Therefore, these interviews do not create social environments that are open to architectural society. Interview $x$ Socialization relationship could not be established. 


\section{Interview x Creating Public Opinion}

It has been observed that; 'An Interview with TED Founder and Architect', 'Heatherwick and MAD on Innovation in Architecture', 'One Day All the Dreamers Will Get Together to Build a Fantastic World: In Conversation with Massimiliano and Doriana Fuksas', 'Steven Holl: I am interested in Architecture that Speaks to the Soul', 'Hello Wood Team on How to Create a Strong Community in a Week', 'Open More Doors: Supervoid' and 'Open More Doors: Studio Gang' interviews have comments from readers. Therefore, readers have an opinion about those articles. Hence Interview x Creating Public Opinion relationship could be established, but not for all interviews.

\section{Interview x Entertainment}

Besides these interviews ("Diversity Fosters Creativity": Rohan Silva on Building a Creative Community for Los Angeles, Heatherwick and MAD on Innovation in Architecture, Carlo Ratti and Winy Maas Discuss Facial Recognition and the Shenzhen Biennale, Erieta Attali: "I Create Images That Capture an Identity of Place", "One Day All the Dreamers Will Get Together to Build a Fantastic World": In Conversation with Massimiliano and Doriana Fuksas, Steven Holl: "I am interested in Architecture that Speaks to the Soul", Junya Ishigami: "Innovation Comes From Each One of Us") all interviews has broadcast via video or sound. Although Interview x Entertainment relationship could not be established for all interviews, it has appeared that the strongest link with entertainment is in the interview headline.

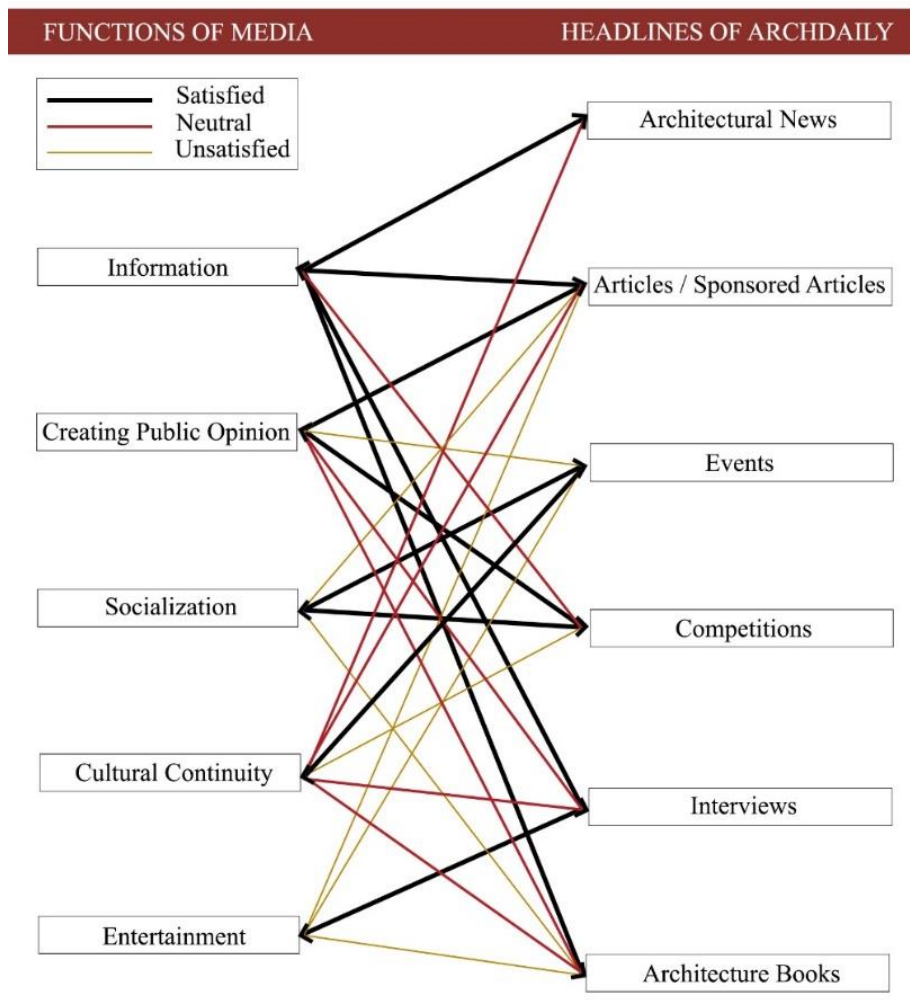

Figure 5. Findings of Qualitative Research 


\section{DISCUSSION}

The present study aimed to draw a new framework for architectural media assessment. Archdaily platform has been taken into consideration to measure and to find an answer to the question of 'How does Archdaily operate as a new architectural medium?'. Various variables have been determined to correspond to the media definition. According to Katz (1960), Burton, G., \& Marshall, P. D. (1993) and McQuail, D. (1987) the media has five basic functions. The five variables (information, cultural continuity, creating public opinion, socialization, and entertainment) and seven variables: Headlines of Archdaily; 'Architectural News', 'Article', 'Competitions', 'Events', 'Sponsored Article', 'Architecture Books' and 'Interview' were considered as integral parts of the approach. An annual (2019) analysis was conducted by two types of research: qualitative and quantitative, to see if the effects were inconsistent regarding the 5 functions of the media.

Research Question 1: Quantitative analyses were performed to diagnose the question: On what percentages the information, creating public opinion, socialization, entertaining and cultural continuity variables were affecting the architectural environment? The findings of quantitative research support the idea that providing the information is the variable that has the most significant impact on the architectural environment via newly emerging digital platforms. In other words, getting information from the new media medium about the discipline of architecture is more effective than the other 4 media functions (figure 4). Archdaily platform provides 5 functions of digital media as; $84.07 \%$ 'Information', 82,94\% 'Creating Public Opinion', 41,78\% 'Socialization', 39,40\% 'Cultural Continuity' and 38,16\% 'Entertainment', respectively (Figure 4). The hypothesis 'Archdaily operate as a new architectural medium' could not be verified. Although Archdaily provides 5 functions, it could not provide all of these functions sufficiently. Only 'Information' and 'Creating Public Opinion' categories have been sufficiently provided, and the categories of 'Socialization', 'Cultural Continuity' and 'Entertaining' were considered inadequate since it was observed that these categories remained below $50 \%$.

Research Question 2: Effects of media function characteristics on headlines of Archdaily platform analyses were run to diagnose how do media functions manifest in Archdaily? Figure 5 displays the findings. Results show that not all headlines were homogeneous. According to Figure 5, Architectural News, Articles/Sponsored Articles, Interviews, and Architecture Books are the satisfying variables in the Information function. Articles/Sponsored Articles and Competitions are satisfying variables in the Creating Public Opinion function. Events and Competitions are satisfying variables in the Socialization function. Events are the only satisfying variable in the Cultural Continuity function and Interviews are the only satisfying variable in the Entertainment function. The weak correlation the research diagnosed in Creating public opinion x Event, Socialization x Articles / Sponsored Articles, Socialization x Architecture Books, Cultural continuity x Competitions, Entertainment x Articles / Sponsored Articles and Entertainment x Events. Findings indicated that the content of the publications regarding the five media functions had an impact on Archdaily headlines. Thus, Archdaily headlines become a concept closely related to the contents of publications. According to the statement of Marshall McLuhan, 'The medium is the message' (McLuhan \& Fiore, 1967) means eventually, the medium that people use starts to be the message to be given. After a while, the medium that is used goes beyond giving a message. Thus, a new cultural environment without a medium is created. According to this statement, could 
Archdaily be telling us about the 21 st-century architectural history by its publications? In this article, it is thought that the architectural history of the 21st century is still being written, and everything that is said/published/broadcasted in new architectural mediums have shaped the history of architecture in the 21 st century. Therefore, in the history of 21 st-century architecture, anyone who has access to the internet may be part of the discourse. Everyone could leave a mark on new architectural mediums and the one might be on the way to be part of architectural history.

All these findings draw a framework for newly emerging architectural digital platforms in contemporary architectural culture: Archdaily platform has a satisfying effect on (i) informing the architectural society via Architectural News, Articles/ Sponsored Articles, Interviews and Architecture Books, (ii) Creating/shaping public opinion via Articles/Sponsored Articles and Competitions. Archdaily needs to provide the functions of the media completely and increase its activities in all fields and even surprise or exceed the theory ( 5 functions) by adding new activities to operate as a new architectural medium.

\section{CONCLUSION}

The novelty of the present study is its multidimensional framework for a concept that has not been studied explicitly before. The study underlined the digital media requirements for the Archdaily platform, therefore diagnosed the contribution of digital media to contemporary architectural culture. In this study, the 'audience' is the 'other side' and the audience's reaction should be included in future research, this article is limited with the digital content created by the Archdaily editors.

Digital media platforms are increasing in number every day and they put the profession at a critical point where architecture is more open and accessible. Contemporary architectural culture is affected by digital platforms. This study indicated that although "giving information" and "creating/forming a public opinion" were the highly accomplished (over 80 percent) functions, "socializing," "providing cultural continuity" and "entertainment" (less than 50 percent) were the functions that needed improvement to qualify Archdaily as (one of) the new architecture media. Furthermore, qualitative research indicated that media functions show inconsistency according to Archdaily's publications in Figure 5. Therefore, the contents of the publications have different effects on the architectural environment.

Briefly, it is possible to claim that the Archdaily platform gives an idea to the world of architecture about 21 st-century architectural history, creates a new environment for architectural culture, and reshape the 21st-century architectural history as Lev Manovich state before '...virtual environments will reshape the visual language of contemporary culture...' (Manovich, 2001). Maybe 10 years from now, unpredictable environments will be created and architectural history will be shaped via those environments. Newly emerged online architectural mediums could become old fashioned. Briefly, it is not important that the medium where the content circulates, it is important that how the medium transfer this message to the readers and what is the message given from the medium.

Recommendations for both Archdaily and newly emerging architectural platforms can be as follows; 
- Since such environments are more preferred to theory and books, especially by young architecture students, contents should not only inform but also socialize, keep cultural continuity, and entertain the architectural community,

- In addition to paying attention to message content, these platforms should also consider how the message will have an impact on society,

- To correct the imbalance observed in Figure 5, each content must be able to address each function,

- Considering the architects doing academic research, adding a section where academic research is circulated can take these platforms to a further next level,

- Finally, to improve the cultural continuity function, these platforms can produce a printed booklet of publications at the end of the year. In this way, a physical mark could be left on the history of architecture by meeting at a common point with traditional printed architecture magazines.

\section{REFERENCES}

Alexa. (2019). The top 500 sites on the web. Retrieved from https://www.alexa.com/topsites/category/Top/Arts/Architecture

Archdaily. (2019). 2019 in Review. Retrieved from https://www.archdaily.com/tag/adtopic2019-year-review

Archdaily. (2019a). Archdaily Main Page. Retrieved from www.archdaily.com

Archdaily. (2019b). Partners of Archdaily. Retrieved from https://www.archdaily.com/advertise

Arklan, Ü., \& Akdağ, M. (2016). Gündelik Yaşamın Sosyal Medyası, Sosyal Medyanın Gündelik Yaşamı: İlişkisel Ve Etkileşimsel Perspektiften Uygulamalı Bir Çalışma. Süleyman Demirel Üniversitesi Vizyoner Dergisi, 7(16), 16-34.

Arnold, D., Ergut, E. A., \& Ozkaya, B. T. (2006). Rethinking architectural historiography: Routledge.

Başaranoğlu, K. (2018). Mimar kimliğinin inşası ve mimarlık medyasında temsili. (M.Arch thesis). Maltepe Üniversitesi, Fen Bilimleri Enstitüsü, İstanbul.

Boyacıoğlu D.B., E. E. Ö., \& T., E. (2015). Küresel Mimarlık Pazarında Yeni Bir Araç Olarak Dijital Medya. Mimarlık(384), 74-77.

Boyd-Barrett, O., \& Braham, P. (2013). Media, knowledge and power: Routledge.

Burton, G., \& Marshall, P. D. (1993). More than meets the eye: an introduction to media studies//Review. Canadian Journal of Communication, 18(1), 112.

Chandler, D., \& Munday, R. (2011). A dictionary of media and communication. OUP Oxford.

Cimadomo, G., García Rubio, R., \& Shahdadpuri Aswani, V. (2018). Towards a (new) 
Architectural History for a digital age. Archdaily as a dissemination tool for architectural knowledge. Paper presented at the III. International Conference on Architectural Design and Criticism.

Comte, A. (1830). The Positive Philosophy of Auguste Comte (2 Vols), trans. Harriet Martineau from the French volumes of, 42.

Douglas, S. J. (2013). Listening in: Radio and the American imagination. London: U of Minnesota Press.

Fischer, S. R. (2003). History of writing. Reaktion books.

Göker, G. (2017). Dijital heterotopyalar:"Başka” bir bağlamda yeni medya. Selçuk İletişim, 9, 164188.

Karaca, A. K. (2010). Medyanın mimarlığa etkisi, mimar imgesinin oluşumunda medyayın rolü (Doctoral dissertation, DEÜ Fen Bilimleri Enstitüsü).

Katz, E. (1960). Communication research and the image of society convergence of two traditions. American Journal of Sociology, 65(5), 435-440.

Klapper, J. T. (1960). The effects of mass communication. New York, NY, US: Free Press.

Manovich, L. (2001). The language of new media: MIT press.

McLuhan, M., \& Fiore, Q. (1967). The medium is the message. New York, 123, 126-128.

McQuail, D. (1987). Mass communication theory: An introduction. Sage Publications, Inc.

McQuail, D., \& Windahl, S. (2015). Communication models for the study of mass communications: Routledge.

Mora, N. (2008). Medya, toplum ve haber kaynağı olarak sembolik seçkinler. Uluslararası İnsan Bilimleri Dergisi, 5(1), 1-25.

Moret, A. (2013). The Nile and Egyptian Civilization: Routledge.

Newhall, B. (1949). The history of photography: From 1839 to the present day (rev. ed.) New York: Museum of Modern Art. Original work published.

Oskay, Ü. (1993). XIX. yüzyıldan günümüze kitle iletişimin kültürel işlevleri. In (pp. 446). İstanbul: Der Yayınları, İstanbul.

Purdy, D. (2008). The Building in Bildung: Goethe, Palladio, and the Architectural Media. Goethe Yearbook, 15, 57-73. doi:10.1353/gyr.2008.0020

Schmandt-Besserat, D. (2010). How writing came about. Austin: University of Texas Press.

Urquhart, P., \& Heyer, P. (2018). Communication in History: Stone Age Symbols to Social Media. Routledge.

Veil, S. R., \& Ojeda, F. (2010). Establishing media partnerships in crisis response.

Communication Studies, 61(4), 412-429. 


\section{ACKNOWLEDGEMENTS}

Authors are thankful to Çiğdem Çidaml for their short yet intense contributions for language control of the article.

\section{CONFLICT OF INTEREST STATEMENT}

There is no such budget/fund has been received for conducting the research or for the preparation of the article.

\section{AUTHOR CONTRIBUTION STATEMENTS}

Işıl ESEN and Pınar DINÇ KALAYCI developed the initial idea and concept of the study. Işıl ESEN and Pınar DINÇ KALAYCI designed the study and the methodology. Işıl ESEN did a detailed literature review as well as collected and processed the data. Pınar DINCC KALAYCI supervised the project. Işıl ESEN and Pınar DINÇ KALAYCI analysed and interpreted the data. Işıl ESEN supplied the resources. Pınar DINCC KALAYCI did Critical Review. All authors contributed to the writing of the text and forming the final version of the manuscript.

\section{BIOGRAPHIES OF THE AUTHORS}

\section{Iş11 ESEN}

Iş1 Esen is an architect and in her final year of M.Arch at Faculty of Architecture Gazi University. She graduated with Honors from Atılim University at the department of architecture (with \% 50 scholarship) in June 2018. During her undergraduate program at Atilim University, she was elected 'High Honor Student' for once and 'Honor Student' for four times. Some of her projects were deserved to be exhibited. Her researches focus on architectural history and theory. Iş1 Esen can be contacted at: archisilesen@yahoo.com.

\section{Pınar DİNÇ KALAYCI (Prof. Dr.)}

Prof. Dinç Kalayc1 received her undergraduate and graduate degrees from Faculty of Architecture, Gazi University (Turkey). During her academic career in the same institute, she worked as a visitor instructor in Belgium for a semester, gained teaching experience in Rome and Ljubljana via Erasmus mobility, participated to several national / international congresses, wrote several articles in Turkish and English, published two books, supervised several theses, conducted research projects funded by The Scientific and Technological Council of Turkey and performed several administrative duties. She runs StudioThinkImagine, one of the design studios of the Department, since 2013. She acted as jury member In 2019 and 2020 in World Architecture Festival. Criticism, education, user satisfaction, programming and competitions are among her topics of interest. Pinar Dinç Kalaycı can be contacted at: pinarpinardinc@gmail.com. 